\title{
Uji Larvasida Ekstrak Etanol Pare (Momordica charantia L.) Terhadap Larva Nyamuk Aedes spp.
}

\author{
Parawansah $^{1 *}$, Arimaswati ${ }^{2}$, Risky Sesa Rini $^{3}$, Nuralifah $^{4}$ \\ ${ }^{1}$ Bagian Farmakologi Fakultas Kedokteran Universitas Halu Oleo, Kampus Hijau Bumi Tridharma Anduonohu, Kendari 93232 \\ ${ }^{2}$ Bagian Parasitologi Fakultas Kedokteran Universitas Halu Oleo, Kampus Hijau Bumi Tridharma Anduonohu, Kendari 93232 \\ ${ }^{3}$ Program Studi Pendidikan Dokter, Fakultas Kedokteran Kampus Hijau Bumi Tridharma Anduonohu, Kendari 93232 \\ ${ }^{4}$ Fakultas Farmasi Universitas Halu Oleo, Kampus Hijau Bumi Tridharma Anduonohu, Kendari 93232
}

E-mail: parawansah biom@yahoo.acom

\begin{abstract}
Abstrak
Pencegahan kejadian DBD dengan penggunaan temefos yang terbuat dari bahan sintetis sudah mengalami resistensi di beberapa daerah sehingga diperlukan larvasida yang berasal dari bahan alam yang efektif. Buah pare yang mengandung alkaloid, flavonoid dan saponin dapat dijadikan alternatif sebagai antiparasit. Penelitian ini bertujuan untuk menguji ekstrak etanol buah pare dan granul ekstrak etanol buah pare (Momordica charantia L.) sebagai larvasida terhadap larva nyamuk Aedes spp. Penelitian ini menggunakan studi eksperimental laboratorium dengan desain pre and post test. Pengujian larvasida ekstrak etanol buah pare dengan konsentrasi 10, 13, 16, dan $19 \mathrm{mg} / 100 \mathrm{~mL}$. Granul ekstrak etanol buah pare dibuat dengan dengan massa $100 \mathrm{mg}$, Temefos 0,02 ppm sebagai kontrol positif, akuades sebagai control negatif, serta granul plasebo (non ekstrak). Hasil penelitian menunjukkan nilai $\mathrm{LC}_{50}$ dan LT 50 berdasarkan analisis regresi log probit dengan nilai LC 50 pada pengamatan 10,080 menit adalah 48,9 mg/100mL dan LT 50 pada konsentrasi $19 \mathrm{mg} / 100 \mathrm{~mL}$ adalah 144,543,9771 menit. Kematian larva pada pengujian ekstrak etanol buah pare mencapai $29 \%$ pada konsentrasi $16 \mathrm{mg} / 100 \mathrm{~mL}$ dan mortalitas dari pengujian granul ekstrak etanol buah pare adalah $2 \%$. Ekstrak etanol buah pare efektif pada konsentrasi $16 \mathrm{mg} / 100 \mathrm{~mL}$ dan granul ekstrak buah pare tidak efektif sebagai larvisida terhadap Aedes spp.
\end{abstract}

Kata kunci: Momordica charantia L., Aedes spp., granul,

\section{Pendahuluan}

Demam dengue (Dengue Fever/DF) dan Demam Berdarah Dengue atau DBD (Dengue Haemorrahge Fever/DHF) adalah penyakit infeksi yang disebabkan oleh virus dengue. Penularan virus dengue terjadi melalui vektor nyamuk genus Aedes (terutama Ae. Aegypti dan Ae. Albopictus) [1]. Indonesia merupakan negara endemis DBD dengan sebaran di seluruh wilayah tanah air, dimana pada tahun 2015 tercatat sebanyak 126.675 penderita DBD di 34 provinsi di Indonesia dengan 1.229 orang di antaranya meninggal dunia [2].

Metode pengendalian vektor telah banyak diketahui dan digunakan dalam program pengendalian DBD yaitu manajemen lingkungan, pengendalian biologis, pengendalian kimiawi, partisipasi masyarakat, perlindungan individu dan peraturan perundangan. Pengendalian secara kimiawi dengan menggunakan insektisida merupakan program yang paling populer, tetapi penggunaan secara terus-menerus dan lama akan menimbulkan resistensi vektor [3].

Kondisi resistensi terhadap insektisida saat ini mengharuskan kita untuk mencari alternatif lain dalam penyelesaian masalah terhadap vektor DBD. Salah satunya adalah penggunaan larvasida alami yang berasal dari tanaman yaitu pare. Pare adalah salah satu tanaman yang memiliki efek larvasida degan nilai 130 ppm [4]. Senyawa yang berfungsi sebagai larvasida dalam buah pare adalah alkaloid, saponin, flavonoid, triterpenoid, dan minyak lemak (linoleat) [5].

\section{Metode}

\subsection{Umum}

Penelitian ini dilakukan di Laboratorium Terpadu Fakultas Kedokteran dan Laboratorium Farmasi Fakultas Farmasi Universitas Halu Oleo. Buah pare diperoleh dari Desa Duriaasi, Kecamatan Wonggeduku, Kabupaten Konawe, Provinsi Sulawesi Tenggara. Lokasi penyimpanan ovitrap untuk mendapatkan telur nyamuk Aedes spp. berlokasi di perumahan warga di Kecamatan Kambu, Kelurahan Kambu, Kota Kendari, Sulawesi Tenggara.

\subsection{Ekstraksi}

Buah pare sebanyak $4 \mathrm{~kg}$ dipreparasi dan dikeringkan. Sebanyak 335,63 gram buah pare kering yang telah dicacah kasar dimaserasi dengan etanol 96\% selama $3 \times 24$ jam pada suhu kamar dengan beberapa kali pengadukan. Filtrat yang didapat diuapkan dengan rotary vacuum evaporator pada suhu $45-50^{\circ} \mathrm{C}[6]$. 


\subsection{Penyiapan Larva Uji}

Telur nyamuk Aedes spp. yang diperoleh dari pemasangan ovitrap di perumahan warga di kelurahan Kambu, ditetaskan dengan meletakkan kertas saring yang berisi telur ke dalam nampan plastik yang berisi air setinggi $3 / 4$ nampan plastik. Setelah telur menetas menjadi larva, maka larva dipindahkan ke nampan plastic lain yang telah diisi air setinggi $3 / 4$ nampan plastik dan diberi makan hati ayam pada setiap nampan plastik. Setiap 2 hari, air diganti dengan yang baru [7].

\subsection{Uji Aktivitas Larvasida Ekstrak}

Pengujian ekstrak etanol buah pare (Momordica charantia L.) dilakukan untuk mencari nilai $\mathrm{LC}_{50}$ dengan menggunakan empat varian konsentrasi yaitu $10 \mathrm{mg} / 100$ $\mathrm{mL}, 13 \mathrm{mg} / 100 \mathrm{~mL}, 16 \mathrm{mg} / 100 \mathrm{~mL}$, dan $19 \mathrm{mg} / 100 \mathrm{~mL}$. Setiap konsentrasi masing-masing akan ditimbang lalu dilarutkan menggunakan DMSO 10\%, Sampel kemudian dilarutkan ke dalam akuades. Setiap kontainer kemudian diisikan larva Aedes spp. instar III/IV sebanyak 25 larva. Pengujian akan dilakukan sebanyak empat kali pengulangan dan setiap perlakuan akan diamati dalam 24 jam sampai 7x24 jam. Analisis data menggunakan analisis regresi log probit untuk menentukan nilai $\mathrm{LC}_{50}$ dan $\mathrm{LT}_{50}$.

\subsection{Pembuatan Granul Ekstrak}

Pembuatan granul pada penelitian ini menggunakan metode granulasi kering. Granul dibuat dengan menggunakan ekstrak etanol buah pare menggunakan nilai $\mathrm{LC}_{50}$. Bahan pengisi yang digunakan untuk membentuk massa granul adalah laktosa, bahan pengikat massa granul adalah PVP (Polivinilpirolidon). Bahan yang diperlukan ditimbang sesuai dengan yang diperlukan dan dicampur sampai homogeny. Setelah semua bahan berubah menjadi granul, lalu dikeringkan menggunakan oven pada suhu 40$50^{\circ} \mathrm{C}$. Setelah granul tersebut kering, granul kemudian kembali diayak menggunakan ayakan [8], sedangkan untuk pembuatan granul placebo menggunakan metode granulasi basah.

\subsection{Uji Aktivitas Granul Ekstrak}

Sebanyak $100 \mathrm{~mL}$ akuades serta larva nyamuk yang sudah mencapai instar III/IV dimasukkan ke dalam tiga kontainer yang berbeda. Jumlah larva yang dimasukkan ke dalam tiap-tiap kontainer adalah 25 larva. Tujuh kontainer ini terdiri dari 3 kelompok perlakuan yaitu kelompok granul uji, kelompok kontrol negatif, dan kelompok placebo. Massa awal granul yang akan diujikan dalam kontainer uji adalah $100 \mathrm{mg}$ untuk $100 \mathrm{~mL}$ air.

\subsection{Analisis Data}

Data aktivitas tersebut dianalisis dan dihitung nilai $\mathrm{LC}_{50}$ dan $\mathrm{LT}_{50}$ menggunakan persamaan regresi linier dengan sumbu $\mathrm{x}$ adalah konsentrasi larutan uji, sedangkan sumbu y adalah persentase kematian larva.

\section{Hasil dan Pembahasan}

Sampel setelah dimaserasi menghasilkan ekstrak sebesar 55,61 gram dengan rendemen $16,57 \%$, dan telur nyamuk yang diperoleh dari pemasangan ovitrap sebanyak \pm 2100 . Persentase kematian larva pada pengujian ekstrak etanol buah pare terlihat pada Gambar 1.

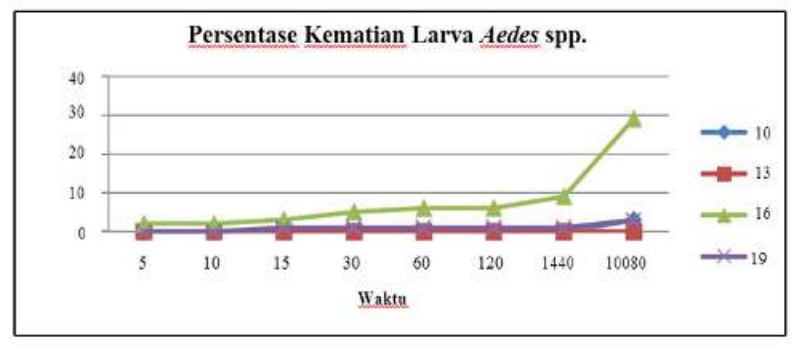

(a)

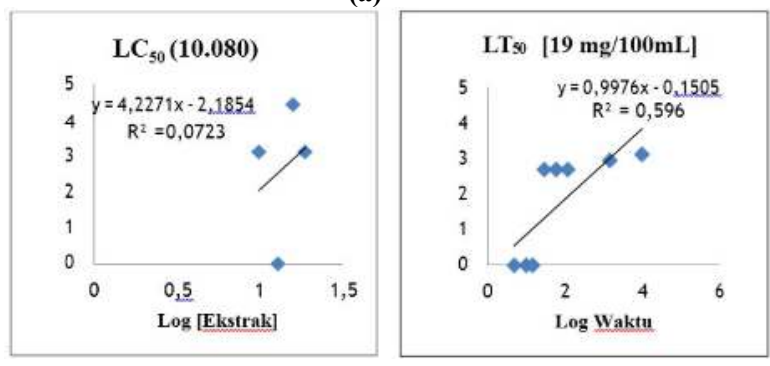

(b)

Gambar 1. (a) Persentase kematian larva pada pengujian ekstrak etanol buah pare; (b) Persamaan garis untuk nilai $\mathrm{LC}_{50}$ dan $\mathrm{LT}_{50}$

Berdasarkan Gambar 1, persentase kematian larva Aedes spp. setelah pengamatan $7 \times 24$ jam, konsentrasi terkecil yang menimbulkan efek larvasida adalah 10 $\mathrm{mg} / 100 \mathrm{~mL}$ dengan persentase mortalitas sebesar 3\%. Konsentrasi dengan nilai mortalitas sebesar 29\% adalah $16 \mathrm{mg} / 100 \mathrm{~mL}$. Sedangkan konsentrasi $13 \mathrm{mg} / 100 \mathrm{~mL}$ memiliki persentase mortalitas sebesar $0 \%$ dan konsentrasi $19 \mathrm{mg} / 100 \mathrm{~mL}$ memiliki persentase mortalitas sebesar 3\%. Mortalitas pada kontrol positif adalah $100 \%$ dan mortalitas pada kontrol negatif adalah $0 \%$. Persentase kematian pada konsentrasi tertinggi yaitu $19 \mathrm{mg} / 100 \mathrm{~mL}$ sama dengan konsentrasi $10 \mathrm{mg} / 100 \mathrm{~mL}$ yaitu 3\%. Hal tersebut dapat dipengaruhi oleh kejenuhan kelarutan bahan pada suatu pelarut, sehingga menurunkan efek bahan tersebut terhadap target [9].

Berdasarkan kurva yang diperoleh pada Gambar $1 \mathrm{~b}$, Nilai LC $_{50}$ pada menit ke-10.080 adalah $48,9 \mathrm{mg} / 100 \mathrm{~mL}$. Nilai $\mathrm{LT}_{50}$ yang diperoleh adalah $144.543,9771$ menit. Nilai LC $_{50}$ yang diperoleh digunakan sebagai massa senyawa aktif pada pembuatan granul. Hasil pengujian larvasida granul ekstrak setelah pengamatan $2 \times 24$ jam persentase kematian larva Aedes spp setelah pemberian granul sebesar $2 \%$. Kontrol positif yaitu menggunakan larutan Abate $^{\circledR}$ yang mengandung temefos 0,02 ppm memiliki persentase kematian larva Aedes spp sebesar $100 \%$. Kontrol negatif sendiri menunjukkan persentase kematian larva sebesar $0 \%$.

Perbedaan tingkat toksisitas pada setiap ekstrak bergantung pada kandungan insektisida setiap ekstrak, tingkat kelarutan pada berbagai macam pelarut yang sangat 
bervariasi pada setiap tanaman, bagian tanaman, usia bagian tanaman yang akan diekstrak, pelarut untuk ekstraksi, variasi musim, dan spesies serangga yang dijadikan target [10]. Efektifitas bahan dipengaruhi oleh kandungan senyawa metabolit sekunder yang kemudian akan memberikan efek mortalitas terhadap larva uji. Kandungan metabolit sekunder dipengaruhi oleh formulasi/komposisi media kultur, fakto fisik (suhu, cahaya, kelembaban dan sebagainya), faktor genetik (genotip sel), faktor stress lingkungan (logam berat, elicitor, sinar UV) [11].

Ekstrak etanol buah pare tidak dapat larut secara keseluruhan dan masih terdapat sampel yang menggumpal. Sampel ekstrak uji dilarutkan terlebih dahulu menggunakan DMSO 10\%. Kondisi tersebut mempengaruhi kelarutan senyawa dari ekstrak etanol buah pare yang memiliki efek sebagai larvasida, sehingga belum bisa memberikan efek yang maksimal terhadap persentase mortalitas larva. Faktor yang mempengaruhi tidak larutnya ekstrak etanol buah pare di dalam pelarut DMSO adalah diduga adanya kandungan senyawa $\beta$ sitosterol. Senyawa $\beta$ sitosterol tidak dapat larut dalam DMSO. DMSO tidak dapat melarutkan senyawa $\beta$ sitosterol karena senyawa sterol memiliki efek memadatkan dan menebalkan membran fosfolipid. Selain itu, senyawa sterol membuat membran menjadi resisten terhadap DMSO. Senyawa $\beta$-sitosterol menurunkan jumlah difusi DMSO sehingga tidak dapat melarutkan [12]. Oleh karena itu, dilakukan uji kelarutan untuk mengetahui pelarut yang dapat melarutkan granul dan ekstrak etanol buah pare. Hasil pengujian kelarutan didapatkan bahwa ekstrak etanol buah pare mudah larut dalam pelarut aseton dan granul ekstrak etanol buah pare sangat sukar larut dalam akuades.

Berdasarkan kriteria WHO, larvasida dinyatakan efektif jika persentase kematian larva uji adalah 10-95\% [16]. Formulasi granul ekstrak etanol buah pare hanya memiliki persentase kematian sebesar $2 \%$, sehingga tidak efektif sebagai larvasida, sedangkan pada ekstrak etanol buah pare efektif sebagai larvasida pada konsentrasi 16 $\mathrm{mg} / 100 \mathrm{~mL}$ dengan persentase mortalitas mencapai $29 \%$.

\section{Kesimpulan}

Ekstrak etanol buah pare (Momordica charantia L.) efektif sebagai larvasida terhadap larva nyamuk Aedes spp. pada konsentrasi $16 \mathrm{mg} / 100 \mathrm{~mL}$. Formulasi granul ekstrak etanol buah pare tidak efektif sebagai larvasida terhadap larva nyamuk Aedes spp.

\section{Ucapan Terima Kasih}

Terima kasih kami ucapkan kepada semua pihak yang telah terlibat dalam penelitian yang kami lakukan baik itu pihak Laboratorium Farmasi dan Laboratorium Terpadu
Fakultas Kedokteran Universitas Halu Oleo, maupun yang terlibat dalam pengolahan data hasil penelitian.

\section{Daftar Pustaka}

1. Sudoyo AW, Setiyohadi B, Alwi I, Simadibrata M, Setiati S, Buku Ajar Ilmu Penyakit Dalam. Jakarta: Interna Publishing, 2009.

2. Kementerian Kesehatan Republik Indonesia. Infodatin Pusat Data dan Informasi Kementerian Kesehatan RI. Jakarta: Kementerian Kesehatan Republik Indonesia, 2016.

3. Sukowati S. Buletin Jendela Epidemiologi Topik Utama Demam Berdarah Dengue. Jakarta: Pusat Data dan Surveilans Epidemiologi Kementerian Kesehatan RI, 2010.

4. Astriani Y, Widawati M. Potensi Tanaman Di Indonesia sebagai Larvasida Alami Untuk Aedes aegypti. Jurnal Spirakel, 2010, 8(2):37-46.

5. Subahar TSS. Sehat Dengan Ramuan Tradisional Khasiat dan Manfaat Pare Si Pahit Pembasmi Penyakit. Depok: Agromedia Pustaka, 2004.

6. Sulfa LZ. Uji Efektivitas Antibakteri dan Antifungi Ekstrak Etanol Buah Pare (Momordica charantia L.) Terhadap Pertumbuhan Escherichia coli, Staphylococcus aureus, dan Candida albicans. Skripsi. Fakultas Kedokteran Universitas Halu Oleo, 2017.

7. Gama ZP, Yanuwiadi B, Kurniati HT. Strategi Pemberantasan Nyamuk Aman Lingkungan: Potensi Bacillus thuringiensis Isolat Madura Sebagai Musuh Alami Nyamuk Aedes aegypti. Jurnal Pembangunan dan Alam Lestari, 2010, 1(1):2087-3522

8. Badan Pengawas Obat dan Makanan. Pedoman Teknologi Formulasi Sediaan Berbasis Ekstrak Volume 2. Jakarta: Badan Pengawas Obat dan Makanan Republik Indonesia, 2013.

9. Willybrordus YPAP, Rini H. Review: Teknik Peningkatan Kelarutan Obat. Jurnal Farmaka Suplemen, 2017, 14(2): 288-297

10. Gandung P, Aulung A, Mila C. Uji efektivitas ekstrak buah pare (Momordica charantia) pada mortalitas larva Aedes Aegypti. Jurnal Profesi Medika, 2016, 10(1):46-53

11. Mariska I. Metabolit Sekunder: Jalur pembentukan dan kegunaannya. http://biogen.litbang.deptan. go.id/index.php/ 2013/08/metabolit-sekunder-jalur-pembentukan-dankegunaannya, diakses 3 Maret 2018

12. Hughes ZE, Mancera RL. Molecular dynamics simulations of mixed DOPC- $\beta$ sitosterol bilayers and their interactions with DMSO. http://pubs.rsc.org/content/articlelanding/ 2013/, diakses 1 Februari 2018.

13. Rochmat A, Napitasari M, Karina AM. Efikasi Granul Biolarvasida Nyamuk Aedes aegypti dari Ekstrak Etil Asetat Daun Beluntas. Jurnal Penelitian Saintek, 2017, 22(1):15-24

14. Brown TL, Lemay Jr. HE, Bruce E. Chemistry: The Central Science. Australia: Pearson Australia, 2014.

15. Wei D, Wang L, Liu C, Wang B. $\beta$-Sitosterol Solubility in Selected Organic Solvent. Journal of Chemical and Engineering Data, 2010, 55(8):2917-19.

16. World Health Organization. Guidelines For Laboratory And Field Testing of Mosquito Larvicides. Geneva: Department of Communicable Disease Control, Prevention, and Eradication, 2010. 